\title{
Modifying intensification of the hardening of extruded construction gypsum nanocomposites
}

\author{
Authors: \\ Rauf M. Khalikov, \\ Associate Professor, Building Constructions Department, Ufa State Petroleum Technological University; \\ Ufa, Bashkortostan Republic, Russia; rauf_khalikov@mail.ru; \\ Ekaterina A. Sinitsina, \\ Assistant, Building Constructions Department, Ufa State Petroleum Technological University; \\ Ufa, Bashkortostan Republic, Russia; sinitsina.katy@yandex.ru; \\ Elena I. Silantyeva, \\ Master's student, Building Constructions Department, Ufa State Petroleum Technological University; \\ Ufa, Bashkortostan Republic, Russia; silanteva.elena.ufa@gmail.com
}

\begin{abstract}
Alexander N. Pudovkin,
Associate Professor, Department of Production of Building Materials, Kumertau Branch of Orenburg State University; Kumertau, Bashkortostan Republic, Russia; 11pk@rambler.ru

\section{Igor V. Nedoseko,}

Professor, Building Constructions Department, Ufa State Petroleum Technological University;

Ufa, Bashkortostan Republic, Russia; nedoseko1964@mail.ru
\end{abstract}

\begin{abstract}
The processes of controlled hardening of nanomineral gypsum binders and the formation of microstructure that allow obtaining gypsum concrete with specified technological characteristics are analyzed. Innovative approaches to the regulation of strength and water resistance of gypsum nanobinders, the main directions of increasing their durability in concretes and mortars, building constructions and products are considered. Controlled hardening nanogypsum binders is a promising 3-D additive technology.

The mechanism of hardening of gypsum nanocomposites based on calcium sulfate dihydrate and semihydrate is proposed. The kinetics of the process of hydration and setting of nanobinders depending on the content of the components is studied. The increase in strength in the process of hardening of pressed gypsum nanobinders is determined by the content of dihydrate and is accompanied by an increase in the size of needle and plate microcrystals with a thickness of less than $100 \mathrm{~nm}$.
\end{abstract}

Keywords: gypsum nanobinder, hardening, structure formation, semi-dry pressing, water resistance of gypsum concrete.

For citation: Khalikov R.M., Sinitsina E.A., Silantyeva E.I., Pudovkin A.N., Nedoseko I.V. Modifying intensification of the hardening of extruded construction gypsum nanocomposites. Nanotehnologii v stroitel'stve = Nanotechnologies in Construction. 2019 , Vol. 11, no. 5, pp. 549-560. DOI: 10.15828/2075-8545-2019-11-5-549-560.

Machine-readable information on CC-licenses (HTML-code) in metadata of the paper

$<$ a rel="license" href="http://creativecommons.org/licenses/by/4.0/"><img alt="Creative Commons License" style="border-width:0" src="https://i.creativecommons.org///by/4.0/88x31.png" / ></a $><$ br / ><span xmlns:dct="http://purl.org/dc/terms/" href="http://purl.org/dc/dcmitype/Text" property="dct:title" rel="dct:type" $>$ Modifying intensification of the hardening of extruded construction gypsum nanocomposites $</$ span $>$ by $<$ a xmlns:cc="http://creativecommons org/ns\#" href="Nanotehnologii v stroitel'stve = Nanotechnologies in Construction. 2019, Vol. 11, no. 5, pp. 549-560. DOI: 10.15828/2075-8545-2019-11-5-549560" property="cc:attributionName" rel="cc:attributionURL" $>$ Khalikov R.M., Sinitsina E.A., Silantyeva E.I., Pudovkin A.N., Nedoseko I.V. $</ a>$ is licensed under a $<$ a rel="license" href="http://creativecommons.org/licenses/by/4.0/" $>$ Creative Commons Attribution 4.0 International License $</$ a $>.<$ br $/>$ Based on a work at $<$ a xmlns:dct="http://purl.org/dc/terms/" href="http://nanobuild.ru/en_EN/nanobuild-5-2019/" rel="dct:source">http://nanobuild.ru/en_EN/nanobuild-5-2019/</ a $>.<$ br / $>$ Permissions beyond the scope of this license may be available at <a xmlns:cc="http://creativecommons.org/ns\#" href="rauf_khalikov@mail.ru" rel="cc:morePermissions" $>$ rauf_khalikov@mail.ru</a $>$.

The paper has been received by editors: 10.06.2019.

The paper has been received by editors after peer-review: 28.08.2019.

The paper has been accepted for publication: 09.09.2019. 


\title{
Модифицирующее усиление твердения прессованных строительных гипсовых нанокомпозитов
}

\author{
Авторы: \\ Халиков Рауф Музагитович, \\ доцент каф. «Строительные конструкции», ФГБОУ ВО «Уфимский государственный нефтяной технический \\ университет»; г. Уфа, Республика Башкортостан, Россия, rauf_khalikov@mail.ru;

\section{Синицина Екатерина Александровна,} \\ ассистент каф. «Строительные конструкции», ФГБОУ ВО «Уфимский государственный нефтяной технический \\ университет»; г. Уфа, Республика Башкортостан, Россия, sinitsina.katy@yandex.ru;

\section{Силантьева Елена Игоревна,} \\ магистрант каф. «Строительные конструкции», ФГБОУ ВО «Уфимский государственный нефтяной технический \\ университет»; г. Уфа, Республика Башкортостан, Россия, silanteva.elena.ufa@gmail.com;

\section{Пудовкин Александр Николаевич,} \\ доцент каф. «Производство строительных материалов», ФГБОУ ВО «Оренбургский государственный университет, \\ Кумертауский филиал»; г.Кумертау, Республика Башкортостан, Россия, 11 pk@rambler.ru;

\section{Недосеко Игорь Вадимович,} \\ профессор каф. «Строительные конструкции», ФГБОУ ВО «Уфимский государственный нефтяной технический \\ университет»; г. Уфа, Республика Башкортостан, Россия, nedoseko1964@mail.ru
}

Резюме: Проанализированы процессы регулируемого твердения наноминеральных гипсовых вяжущих материалов и формирования микроструктуры, позволяющие получать гипсобетоны с востребованными технологическими характеристиками. Рассмотрены инновационные подходы регулирования набора прочности и водоустойчивости гипсовых нановяжущих, основные направления повышения их долговечности в бетонах и растворах, строительных конструкциях и изделиях. Контролируемое твердение наногипсовых вяжущих считается перспективным в 3-D аддитивных технологиях.

Предложен механизм твердения гипсовых нанокомпозитов на основе дигидрата и полугидрата сульфата кальция. Изучена кинетика процесса гидратации и схватывания нановяжущих в зависимости от содержания компонентов. Нарастание прочности в процессе твердения прессованных гипсовых нановяжущих определяется содержанием дигидрата и сопровождается увеличением размеров игольчатых и пластинчатых микрокристаллов с толщиной менее 100 нм.

Ключевые слова: гипсовые нановяжущие, твердение, структурообразование, полусухое прессование, водостойкость гипсобетонов.

Для цитирования: Халиков Р.М., Синицина Е.А., Силантьева Е.И., Пудовкин А.Н., Недосеко И.В. Модифицирующее усиление твердения прессованных строительных гипсовых нанокомпозитов // Нанотехнологии в строительстве. - 2019. - Том 11, № 5. - C. 549-560. - DOI: 10.15828/2075-8545-2019-11-5-549-560.

Машиночитаемая информация о СС-лицензиях (HTML-код) в метаданных статьи

$<$ a rel="license" href="http://creativecommons.org/licenses/by/4.0/"><img alt="Creative Commons License" style="border-width:0" src="https://i.creativecommons.org///by/4.0/88x31.png" / ></a $><$ br / ><span xmlns:dct="http://purl.org/dc/terms/" href="http://purl.org/dc/dcmitype/Text" property="dct:title" rel="dct:type" $>$ Modifying intensification of the hardening of extruded construction gypsum nanocomposites $</$ span $>$ by $<$ a xmlns:cc="http://creativecommons. org/ns\#" href="Nanotehnologii v stroitel'stve = Nanotechnologies in Construction. 2019, Vol. 11, no. 5, pp. 549-560. DOI: 10.15828/2075-8545-2019-11-5-549560" property="cc:attributionName" rel="cc:attributionURL" $>$ Khalikov R.M., Sinitsina E.A., Silantyeva E.I., Pudovkin A.N., Nedoseko I.V. $</ a>$ is licensed under a $<$ a rel="license" href="http://creativecommons.org/licenses/by/4.0/" $>$ Creative Commons Attribution 4.0 International License $</$ a $>.<$ br $/>$ Based on a work at $<$ a xmlns:dct="http://purl.org/dc/terms/" href="http://nanobuild.ru/en_EN/nanobuild-5-2019/" rel="dct:source">http://nanobuild.ru/en_EN/nanobuild-5-2019/</ a $>$.<br / >Permissions beyond the scope of this license may be available at <a xmlns:cc="http://creativecommons.org/ns\#" href="rauf_khalikov@mail.ru" rel="cc:morePermissions" $>$ rauf_khalikov@mail.ru</a $>$.

Статья поступила в редакцию: 10.06.2019.

Статья поступила в редакцию после рецензирования: 28.08.2019.

Статья принята к публикации: 09.09.2019. 


\section{INTRODUCTION}

$\mathrm{B}$ uilding materials based on clinker-free gypsum binders are characterized by low energy consumption of production (tens of times less than Portland cement), sufficient sound, thermal insulation and other technological advantages. The elaboration of modified nanocomposite pressed gypsum binders, providing products with high physico-mechanical, operational and technical and economic indicators, remains an urgent task.

This article is aimed at studying the kinetics of controlled hardening of gypsum nanobinders.

\section{MAIN PART}

To solve technological problems of increasing the efficiency of hardening processes [1] of gypsum nanoconcrete, it is necessary to control the kinetics of setting and curing. The physico-chemical characteristics of the hardening of gypsum building materials depend primarily on the technology of production of raw materials.

The reserves of gypsum minerals in Russia are practically inexhaustible (only in the Republic of Bashkortostan in explored deposits they amount to over 400 million tons), there is also a large amount of gypsum-containing waste that is suitable for the production of materials for various purposes based on gypsum. Currently, about 250 million tons of gypsum materials based on natural raw materials and industrial wastes are produced annually in the world [2].

The basis of the production of gypsum nanobinders is the heat treatment of gypsum stone, during which phased physicochemical dehydration processes (dehydration) take place. According to the production technology, lowfiring (up to $250^{\circ} \mathrm{C}$ ), high-firing (from $600^{\circ} \mathrm{C}$ to $1000^{\circ} \mathrm{C}$ ) and unbaked plaster binders are distinguished. The degree of dehydration of $\mathrm{CaSO}_{4} \cdot 2 \mathrm{H}_{2} \mathrm{O}$ (calcium sulfate dihydrate) depends on the temperature, conditions and duration of heat treatment. At low-temperature autoclave heat treatment $\left(95-100^{\circ} \mathrm{C}\right) \alpha$-modification of $\mathrm{CaSO}_{4} \cdot 0.5 \mathrm{H}_{2} \mathrm{O}$ is formed (more correctly $2 \mathrm{CaSO}_{4} \cdot \mathrm{H}_{2} \mathrm{O}$ ). $\alpha$-Modification of calcium sulfate hemihydrate consists of large dense crystals that are used in the in technological production of high-strength gypsum (15-20 MPa).

When hydrated water is removed in open technological devices from $\mathrm{CaSO}_{4} \cdot 2 \mathrm{H}_{2} \mathrm{O}$ crystals in the form of steam, its dispersion and loosening of the crystal lattice occurs, and the $\beta$-form of semi-aqueous $\mathrm{CaSO}_{4} \cdot 0.5 \mathrm{H}_{2} \mathrm{O}$ is formed. Calcium sulfate $\beta$-hemihydrate microcrystals are small, defectively formed, therefore, gypsum binders result in significant variations in dispersion, water demand, porosity and reduced strength values.

Low-calcined gypsum binders quickly set and harden, consist mainly of the $\beta$-modification $\mathrm{CaSO}_{4} \cdot 0.5 \mathrm{H}_{2} \mathrm{O}$ and are the basis of the construction and molding gypsum binders. High-calcined gypsum nanobinders harden more slowly, consist mainly of anhydrite (calcium sulphate $\mathrm{CaSO}_{4}$ ) and $3-5 \%$ of calcium oxide and form water-resistant nanocomposites. Unburned gypsum binders are obtained by fine grinding of natural or artificial varieties of calcium sulfate and this allows to reduce the energy consumption for processing raw materials.

The processes of hydration and setting of gypsum binders nanocomposites depend [3] on many different factors: the ratio of the gypsum component-water; mixing intensity and temperature; fine grinding, etc. The physicochemical processes of hardening of calcium sulfate hemihydrate (as well as other gypsum nanobinders) occurs in three stages:

- dissolution of microparticles of hemihydrate in water and the formation of its saturated solution; gypsum nanobinders plastically;

- interaction of water with calcium sulfate hemihydrate, which leads to the formation of $\mathrm{CaSO}_{4} \cdot 2 \mathrm{H}_{2} \mathrm{O}$ dihydrate in the form of ultrafine crystalline microparticles (the dihydrate is significantly less soluble in water ( $2 \mathrm{~g} / \mathrm{l})$ compared to $\mathrm{CaSO}_{4} \cdot 0.5 \mathrm{H}_{2} \mathrm{O}(8 \mathrm{~g} / 1)$ and forms colloid nanosystem due to Van der Waals interactions and is accompanied by the launch of gel-like hardening;

- recrystallization of fine particles of calcium sulfate dihydrate with the topochemical formation of larger crystals and gradual accretion into crystalline intergrowths, which ensures the hardening and curing of gypsum nanocomposites.

Depending on the setting time, gypsum binders vary: from fast-hardening (the start of curing is not earlier than 2 minutes, the end is not later than 15 minutes) to slow hardening (the beginning of hardening is not earlier than 20 minutes, and the end is not normalized). One of the effective ways to control the setting time of gypsum binders is the use of appropriate nano-additives. The production technology of a multi-phase gypsum nanobinders with predominant anhydrite content provides slower setting time.

The stoichiometric water-gypsum binder ratio upon hydration of $\mathrm{CaSO}_{4} \cdot 0.5 \mathrm{H}_{2} \mathrm{O}$ to dihydrate is 0.18 : this means that about $18 \%$ of water is required to be added. An additional amount of water (up to 30-40\%) must be added to produce a conveniently molded gypsum paste. The kinetics of the setting of gypsum nanobinders are also influenced by the fineness of the grinding, the storage time of the raw material and other factors [4].

Theoretical and experimental studies [5-9] of the mechanisms for the hardening of gypsum nanobinders showed that the formation of a crystallization nanostructure occurs when the following conditions are met:

- microparticles of the dispersed phase should be at a sufficiently small distance $h_{c}$ at which the formation of crystallization nanocontacts between them is possible; 
- the concentration of the solute in the dispersed medium must be greater than the solubility of the crystalline hydrate, i.e. the system must be metastable. The higher the supersaturation of the solution, the greater can be the distance between the merging particles of the hydrate, at which crystallization nanostructure can be formed.

The distance between microparticles $h_{c}$, which ensures the formation of nanocrystallization contacts according to the data of [5], should be equal to $\sim 3 \delta_{0}\left(\delta_{0}-\right.$ intermolecular distance). It is not possible to bring crystalline hydrate particles of gypsum dihydrate to the required distance by ordinary technological methods, in particular, injection molding technology, therefore, non-trivial methods of molding are being developed. When pressing semi-dry mixtures, it is also difficult to bring the particles of dihydrate gypsum to the distance required to form a crystallization nanostructure, due to the low water content of the mixture and the low pressing pressure. Consequently, for such gypsum nanobinders, it is necessary to increase the supersaturation of the liquid phase with dihydrate, i.e. to fulfill the second condition for the emergence of a crystal hydrate structure, and this can be achieved by introducing into the composition a certain mass fraction of $\mathrm{CaSO}_{4} \cdot 2 \mathrm{H}_{2} \mathrm{O}$.

Consider the mechanism of hardening nanobinder on the example of a gypsum composition, the solid phase of which consists of dihydrate (DH) and hemihydrate $(\mathrm{HH})$ calcium sulphate. When mixed with water, $\mathrm{HH}$ starts intensively hydrating and dissolving: in a dispersed system, a supersaturated concentration of DH in the form of germ-free crystalline hydrates with a size of $\approx 2 \mathrm{~nm}$ is rather quickly created. However, the spatial crystalline hydrate nanostructure may not be formed if the initial distance between the DH nanoclusters is too large (more than $10 \mathrm{~nm}$ ), i.e. the initial components are not sufficiently compacted, and the number of nanobinder $\mathrm{HHs}$ is not enough so that when it hydrates, the gap between the DH crystals decreases to a critical one.

After the end of the hydration process, $\mathrm{HH}$ of calcium sulfate in the first hours of hardening begins the second stage of the curing of the nanocomposite: by this time, a primary three-dimensional nanostructure has formed, which has initial strength, but with insufficient water resistance. In the future, the existing primary nanostructure is strengthened, as well as an increase in the number of crystallization nanocontacts between unbound microcrystals and their fouling. The second stage of hardening crystal hydrate nanostructures proceeds slowly over several months, depending on the hardening conditions of the gypsum nanobinder [10].

Studies of the microstructure of gypsum nanobinders show that between the lamellar with a thickness of less than $100 \mathrm{~nm}$, the needle-like $\mathrm{CaSO}_{4} \cdot 2 \mathrm{H}_{2} \mathrm{O}$ crystals of various shapes and sizes in the solid phase state have microcavities and micropores [11]. The formed nanostructure of the calcium sulfate dihydrate crystal lattice is layered: a layer of $\mathrm{Ca}^{2+}$ ions and sulfate tetrahedra $\mathrm{SO}_{4}{ }^{2-}$ (connected by strong ionic bonds) alternates with a layer of water molecules. The parameters of the $\mathrm{CaSO}_{4} \cdot 2 \mathrm{H}_{2} \mathrm{O}$ crystal nanostructure are as follows: $a_{0}=0.57 \mathrm{~nm}, b_{0}=$ $1.52 \mathrm{~nm}, c_{0}=0.63 \mathrm{~nm}$.

To regulate the speed of hardening (slowing down at the beginning of the process, accelerating at the end of strength building) of the components of $3 \mathrm{D}$-technologies, various additives are added to the gypsum nanocomposite: for example, $0.05 \%$ citric acid (polydentate inhibitor) slows down the setting by 30 minutes. Various hardening inhibitors reduce the dissolution rate of gypsum hemihydrate, therefore, reduce the concentration of precipitated crystalline hydrates. In particular, the inhibitory effect of adhesives and surface-active substances on the kinetics of setting is explained by the fact that they form stable colloidal nanoparticles that delay the crystallization process of gypsum dihydrate.

The kinetics of hardening and the formation of a primary nanostructure, as well as the effects of dihydrate gypsum, were studied by molding and testing samples of different compositions. For this purpose, samples were made on the basis of the gypsum grade G-4:

gypsum HH nanobinder G-4 (-B-II) - DH ( $\mathrm{S}=$ $3000 \mathrm{~cm}^{2} / \mathrm{g}$ );

gypsum HH nanobinder G-4 (-B-II) - dolomite flour $\left(\mathrm{S}=2600 \mathrm{~cm}^{2} / \mathrm{g}\right)$;

gypsum HH nanobinder G-4 (-B-II) - quartz sand.

The $\mathrm{HH}$ content of the nanobinder varied from 0 to $50 \%$, the water-solid ratio was $0.22 \ldots 0.17$. The prepared cylindrical samples were pressed under a pressure of $20 \mathrm{MPa}$ for $30 \mathrm{~s}$ and tested for compressive strength (CS) at the age of 1 day curing at relative air humidity $\varphi=60 \pm 10 \%$ and temperature $t^{\circ}=20 \pm 2^{\circ} \mathrm{C}$. The results of experimental studies of samples based on gypsum nanobinder strength are presented in Fig. 1.

From figure 1 it is noticeable that dihydrate gypsum is quite actively involved in the formation of the primary nanostructure. In the presence of DH in the system, even with a small $\mathrm{HH}$ content (not more than 10\%), a threedimensional nanocrystallization structure is formed with a sufficiently high strength.

To study the non-hydration curing, hardened samples based on gypsum nanobinders were stored for a month at $\mathrm{t}^{\circ}=20 \pm 2^{\circ} \mathrm{C}$ and relative humidity of the atmosphere $\varphi=60 \pm 10 \%$. The kinetics of changes in the compressive strength of nanocomposite samples is shown in Fig. 2: a noticeable increase in compressive strength occurs in the first 4 days.

The microstructure of gypsum nanocomposites was studied using a JEOL JSM-6610L scanning electron microscope (Fig. 3). Electron microscopic images show an increase in the size of microcrystals over 8 days. 


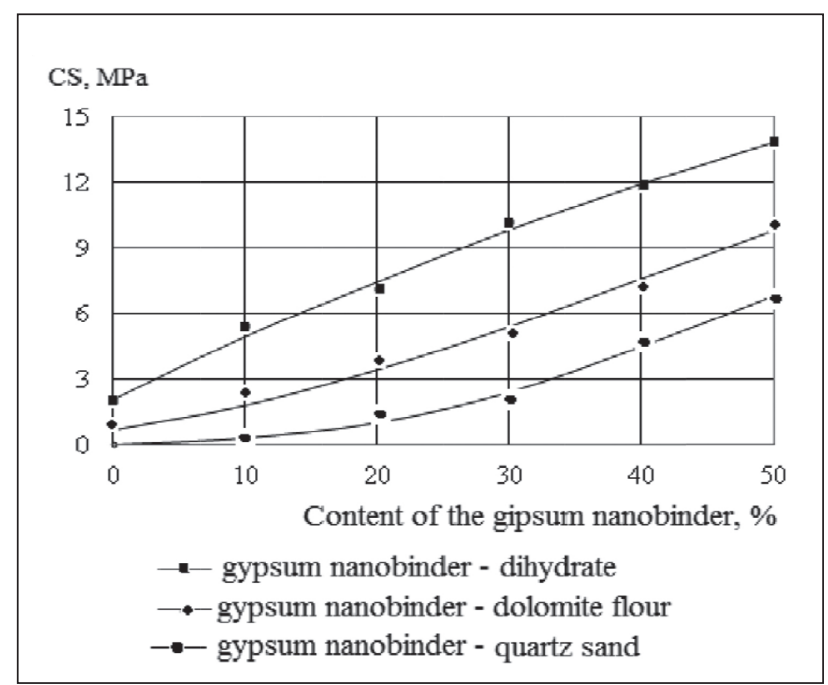

Fig. 1. The dynamics of growth of the strength of samples of different composition depending on the content of gypsum nanobinders at the age of 1 day

On the basis of data from laboratory experiments, a technology was developed for producing small wall and partition products, which was tested in pilot-industrial conditions. Through the use of semi-dry pressing and vibropressing technologies, wall partitioning building materials with sufficient strength have been obtained. The use of nanoparticles of industrial wastes [12-14] allows us to accelerate the kinetics of curing, increase the brand of water resistance and improve the performance characteristics of composite gypsum binders. In the monograph [15], the technology of producing small-piece wall products by semi-dry pressing based on technogenic phosphogypsum dihydrate is considered in detail.

Consideration of structure formation and hardening of phosphogypsum building materials from the perspec-

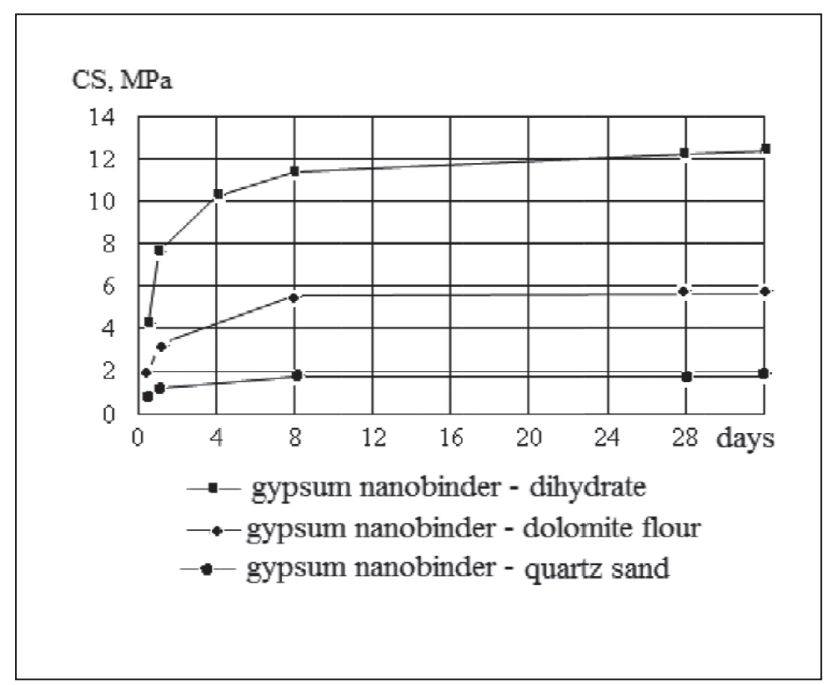

Fig. 2. The change in strength in time of pressed samples of different composition with the content of gypsum nano-binder $20 \%$

tive of the fractal concept is correctly modeled as multifractal calcium sulfate dihydrate nanoclusters with dimensions of several tens of nanometers. [16]. Phosphogypsum nanocomposite with soda production wastes hardens due to complex reactions with the formation of hydrosulfoaluminates and calcium hydrosilicates. The paper [17] proposed a method for quantitative analysis of the images of the microstructure of a nano-modified composite based on performing binary decomposition. The mean values of the fractal dimension for empirical images of the microstructure are 1.63 (optical microscopy) and 1.76 (scanning probe microscopy).

When mechanically activating high-strength gypsum [18], it is advisable to introduce "FREM NANOGIPS" into dry mortar: this reduces the water-gypsum ratio

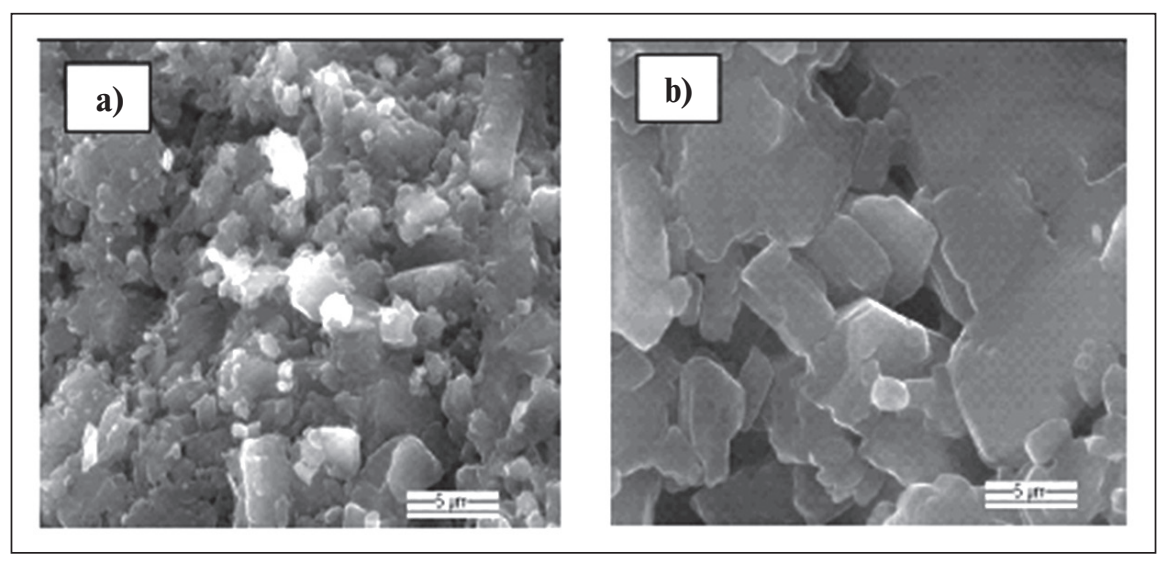

Fig. 3. Microstructure of pressed nanocomposite gypsum matrices

(hardening time: a) - 1 day, b) - 8 days) 
and increases by $3-6$ times the strength characteristics of the resulting nanocomposite gypsum products and materials; allows you to adjust the setting time, enhances water resistance, as well as surface hardness and adhesion [19] to various solid-phase materials. The authors of the article [20] found that the modification of $0.18 \%$ by multi-layered carbon nanotubes is observed to increase the compressive strength of gypsum to $29 \%$.

Innovative materials based on gypsum nanocomposite binders (dry plaster and putty mixtures) are created by modifying $0.25-1 \%$ polyvinyl acetate redispersible polymers [21]. Modified gypsum dry mixes have unique characteristics: the ability to control the setting time in wide ranges; sufficient strength, water resistance, etc.

It should be noted that the regulation of the hardening of gypsum binders is considered promising when designing the initial components of $3 \mathrm{D}$-technologies [22]. Additive technologies are a layered addition of material on a computer 3D model [23] and now designers in the construction industry are increasingly using $3 \mathrm{D}$ printing technologies, which ensures the speed of construction of low-rise buildings with a complex structure. An effective approach to enhancing the performance characteristics of building nanocomposites for 3D additive technologies based on gypsum binders is the implementation of controlled hardening with mineral additives.

\section{CONCLUSION}

Thus, the increase in strength in the process of the hardening of gypsum nanobinders is determined by the chemical and mineralogical composition of the initial raw materials and is parallel to the change in their microstructure. The technological properties of gypsum nanocomposites: setting time, water resistance, durability, etc. can be adjusted by changing the ratio of the individual components and the introduction of technogenic nanomodifiers.

\section{ВВЕДЕНИЕ}

$\mathrm{C}$ тройматериалы на основе бесклинкерных гипсовых вяжуших отличаются малой энергозатратностью производства (в десятки раз меньше чем портландцемент), достаточной звуко-, теплоизоляцией и другими технологическими преимуществами. Разработка модифицированных нанокомпозиционных прессованных гипсовых вяжущих, обеспечивающих получение изделий с высокими физико-механическими, эксплуатационными и технико-экономическими показателями, остается актуальной задачей.

Данная статья нацелена на исследование кинетики регулируемого твердения гипсовых нановяжущих.

\section{ОСНОВНАЯ ЧАСТЬ}

Для решения технологических задач повышения эффективности процессов твердения [1] гипсонанобетонов необходимо управлять кинетикой схватывания и набора прочности. Физико-химические особенности твердения гипсовых стройматериалов зависят, прежде всего, от технологии производства сырьевых компонентов.

Запасы гипсовых минералов в России практически неисчерпаемы (только в Республике Башкортостан на разведанных месторождениях они составляют свыше 400 млн. тонн), имеется также большое количество гипсосодержащих отходов, которые пригодны для производства материалов различно- го назначения на основе гипса. В настоящее время ежегодно в мире вырабатывается около 250 млн. т гипсовых материалов на основе природного сырья и техногенных отходов [2].

Основой производства гипсовых нановяжущих является термообработка гипсового камня, при которой происходят поэтапные физико-химические процессы обезвоживания (дегидратация). По технологии производства различают низкообжиговые (до $250^{\circ} \mathrm{C}$ ), высокообжиговые (от $600^{\circ} \mathrm{C}$ до $1000^{\circ} \mathrm{C}$ ) и безобжиговые гипсовые вяжущие. Степень дегидратации $\mathrm{CaSO}_{4} \cdot 2 \mathrm{H}_{2} \mathrm{O}$ (дигидрата сульфата кальция) зависит от температуры, условий и длительности тепловой обработки. При низкотемпературной автоклавной термообработке $\left(95-100^{\circ} \mathrm{C}\right)$ образуется $\alpha$-модификация $\mathrm{CaSO}_{4} \cdot 0,5 \mathrm{H}_{2} \mathrm{O}$ (более корректно $\left.2 \mathrm{CaSO}_{4} \cdot \mathrm{H}_{2} \mathrm{O}\right)$. $\alpha$-Модификация полугидрата сульфата кальция состоит из крупных плотных кристаллов, которые используются в технологическом производстве высокопрочного гипса (15-20 МПа).

При удалении гидратной воды в открытых технологических аппаратах из кристаллов $\mathrm{CaSO}_{4} \cdot 2 \mathrm{H}_{2} \mathrm{O}$ в виде пара происходит его диспергирование и разрыхление кристаллической решетки, при этом образуется $\beta$-форма полуводного $\mathrm{CaSO}_{4} \cdot 0,5 \mathrm{H}_{2} \mathrm{O}$. Микрокристаллы $\beta$-полугидрата сульфата кальция мелкие, дефективно сформированы, поэтому гипсовые вяжущие получаются значительными вариациями дисперсности, водопотребности, пористости и сниженными значениями прочности. 
Низкообжиговые гипсовые вяжущие быстро схватываются и твердеют, состоят преимущественно из $\beta$-модификации $\mathrm{CaSO}_{4} \bullet 0,5 \mathrm{H}_{2} \mathrm{O}$ и являются основой строительного и формовочного гипсовых вяжущих. Высокообжиговые гипсовые нановяжущие отвердевают медленнее, состоят преимущественно из ангидрита (сульфата кальция $\mathrm{CaSO}_{4}$ ) и $3-5 \%$ оксида кальция и образуют водостойкие нанокомпозиты. Безобжиговые гипсовые вяжущие получают при тонком измельчении природных или искусственных разновидностей сульфата кальция, и это позволяет уменьшить энергозатраты на переработку исходного сырья.

Процессы гидратации и схватывания нанокомпозитов гипсовых вяжущих зависят [3] от множества разнообразных факторов: соотношения гипсового компонента-воды; интенсивности и температуры смешения; тонкости помола и т.п. Физико-химические процессы твердения полугидрата сульфата кальция (так же как и других гипсовых нановяжущих) происходит в три стадии:

- растворение микрочастиц полугидрата в воде и образование его насыщенного раствора; гипсовое нановяжущее пластично;

- взаимодействие воды с полугидратом сульфата кальция, что приводит к образованию дигидрата $\mathrm{CaSO}_{4} \cdot 2 \mathrm{H}_{2} \mathrm{O}$ в виде ультрадисперсных кристаллических микрочастиц (дигидрат значительно менее растворим в воде (2 г/л) по сравнению c $\mathrm{CaSO}_{4} \cdot 0,5 \mathrm{H}_{2} \mathrm{O}$ (8 г/л) и формированию коллоидной наносистемы за счет Ван-дер-Ваальсовых взаимодействий и сопровождается запуском гелеобразного твердения;

- перекристаллизация тонкодисперсных частичек дигидрата сульфата кальция с топохимическим формированием более крупных кристаллов и постепенным срастанием в кристаллические сростки, что обеспечивает твердение и набор прочности гипсовых нанокомпозитов.

В зависимости от сроков схватывания гипсовые вяжущие варьируют от быстротвердеющих (начало отверждения не ранее 2 мин., конец не позднее 15 мин.) до медленнотвердеющих (начало твердения не ранее 20 мин., а конец не нормируется). Одним из эффективных способов регулирования сроков схватывания гипсовых вяжущих является применение соответствующих нанодобавок. Технология производства многофазового гипсового нановяжущего с преимущественным содержанием ангидрита обеспечивает замедленные сроки схватывания.

Стехиометрическое соотношение вода-гипсовое вяжущее при гидратации $\mathrm{CaSO}_{4} \cdot 0,5 \mathrm{H}_{2} \mathrm{O}$ в дигидрат равно 0,18: значит, требуется добавить около $18 \%$ воды. Добавочное количество воды (до 30-40\%) необходимо прибавить для производства удобнофор- муемой пасты гипсовой нановяжущей. На кинетику схватывания гипсовых нановяжущих также влияют тонкость помола, длительность хранения исходного сырья и другие факторы [4].

Теоретические и экспериментальные исследования [5-9] механизмов твердения гипсовых нановяжущих показали, что формирование кристаллизационной наноструктуры происходит при выполнении следующих условий:

- микрочастицы дисперсной фазы должны находиться на достаточно малом расстоянии $h_{\kappa}$, при котором возможно образование кристаллизационных наноконтактов между ними;

- концентрация растворенного вещества в дисперсной среде должна быть больше растворимости кристаллогидрата, т. е. система должна быть метастабильной. Чем выше пересыщение раствора, тем больше может быть расстояние между срастающимися частицами гидрата, при котором возможно образование кристаллизационной наноструктуры.

Расстояние между микрочастицами $h_{\kappa}$, обеспечивающее формирование нанокристаллизационных контактов по данным работы [5], должно быть равно $\sim 3 \delta_{0}\left(\delta_{0}-\right.$ межмолекулярное расстояние). Сблизить кристаллогидратные частицы дигидрата гипса до требуемого расстояния ординарными технологическими приемами, в частности, по литьевой технологии не удается, поэтому разрабатываются нетривиальные способы формования. При прессовании полусухих смесей сблизить частицы дигидрата гипса на расстояние, необходимое для образования кристаллизационной наноструктуры, также затруднено, что обусловлено низким водосодержанием смеси и невысоким давлением прессования. Следовательно, для подобных гипсовых нановяжущих необходимо повысить пересыщение жидкой фазы дигидратом, т.е. выполнить второе условие возникновения кристаллогидратной структуры, а этого можно достичь введением в композицию некоторой массовой доли $\mathrm{CaSO}_{4} \cdot 2 \mathrm{H}_{2} \mathrm{O}$.

Рассмотрим механизм твердения нановяжущей на примере гипсовой композиции, твердая фаза которой состоит из дигидратного (ДГ) и полугидратного (ПГ) сульфата кальция. При затворении водой ПГ начинает интенсивно гидратироваться и растворяться: в дисперсной системе достаточно быстро создается пересыщенная концентрация ДГ в виде зародышевых кристаллогидратов с размером $\approx 2$ нм. Однако пространственная кристаллогидратная наноструктура может не формироваться, если первоначальное расстояние между нанокластерами ДГ слишком велико (больше 10 нм), т.е. исходные компоненты недостаточно уплотнены, а количество нановяжущего ПГ недостаточно для того, чтобы при 
THE ELABORATION OF THE THEORY OF THE FORMATION STRENGTH AND IMPERMEABILITY OF NANOSTRUCTURED SYSTEMS РАЗРАБОТКА ТЕОРИИ ФОРМИРОВАНИЯ ПРОЧНОСТИ И НЕПРОНИЦАЕМОСТИ НАНОСТРУКТУРИРОВАННЫХ СИСТЕМ

его гидратации зазор между кристаллами ДГ уменьшился до критического.

После окончания процесса гидратации ПГ сульфата кальция в первые часы твердения наступает вторая стадия отверждения нанокомпозиции: к этому моменту времени сформировалась первичная трехмерная наноструктура, обладающая начальной прочностью, но с недостаточной водостойкостью. В дальнейшем происходит упрочнение существующей первичной наноструктуры, а также рост числа наноконтактов кристаллизации между несвязанными микрокристаллами и их обрастания. Вторая стадия упрочнения кристаллогидратных наноструктур протекает медленно в течение нескольких месяцев, в зависимости от условий твердения гипсовых нановяжущих [10].

Исследования микроструктуры гипсовых нановяжущих показывают, что между пластинчатыми с толщиной менее 100 нм игольчатыми кристаллами $\mathrm{CaSO}_{4} \cdot 2 \mathrm{H}_{2} \mathrm{O}$ разнообразной формы и размеров в твердофазовом состоянии имеются микрополости и микропоры [11]. Сформированная наноструктура кристаллической решетки дигидрата сульфата кальция слоистая: прослойка из ионов $\mathrm{Ca}^{2+}$ и сульфатных тетраэдров $\mathrm{SO}_{4}{ }^{2-}$ (соединенные прочными ионными связями) чередуется слоем молекул воды. Параметры наноструктуры кристаллов $\mathrm{CaSO}_{4} \cdot 2 \mathrm{H}_{2} \mathrm{O}$ следующие: $a_{0}=0,57 \mathrm{Hм}, b_{0}=1,52 \mathrm{Hм}, c_{0}=0,63 \mathrm{Hм}$.

Для регулирования скорости твердения (замедления в начале процесса, ускорения при завершении набора прочности) компонентов 3D-технологий в гипсовую нанокомпозицию добавляют разнообразные добавки: например, 0,05\% лимонная кислота (полидентантный ингибитор) замедляет схватывание на 30 мин. Разнообразные замедлители твердения понижают скорость растворения полугидрата гипса, следовательно, уменьшают концентрацию выпадающих в осадок кристаллогидратов. В частности, ингибирующее действие клеев и поверхностно активных веществ на кинетику схватывания объясняется тем, что они формируют устойчивые коллоидные наночастицы, которые задерживают процесс кристаллизации дигидрата гипса.

Кинетику твердения нановяжущих и образование первичной наноструктуры, а также влияния дигидрата гипса изучали путем формования и испытания образцов различного состава. Для этого изготовили образцы на основе марки гипса Г-4:

гипсовое ПГ нановяжущее Г-4(-Б-II) - ДГ $\left(\mathrm{S}_{\text {уд. }} \approx 3000 \mathrm{~cm}^{2} /\right.$ Г);

гипсовое ПГ нановяжущее Г-4(-Б-ІІ) - доломитовая мука $\left(\mathrm{S}_{\text {ул. }} \approx 2600 \mathrm{~cm}^{2} / \Gamma\right)$;

гипсовое ПГ нановяжущее Г-4(-Б-ІІ) - кварцевый песок.

Содержание ПГ нановяжущего изменялось от 0 до $50 \%$, водотвердое отношение - 0,22...0,17. Приготовленные образцы цилиндрической формы прессовали под давлением 20 МПа в течение 30 с и испытывали на прочность при сжатии в возрасте 1 сут. твердения при относительной влажности воздуха $\varphi=$ $60 \pm 10 \%$ и температуры $\mathrm{t}^{\circ}=20 \pm 2^{\circ} \mathrm{C}$. Результаты экспериментальных исследований образцов на основе гипсовых нановяжущих на прочность представлены на рис. 1.

Из рисунка 1 заметно, что дигидратный гипс достаточно активно участвует в формировании пер-

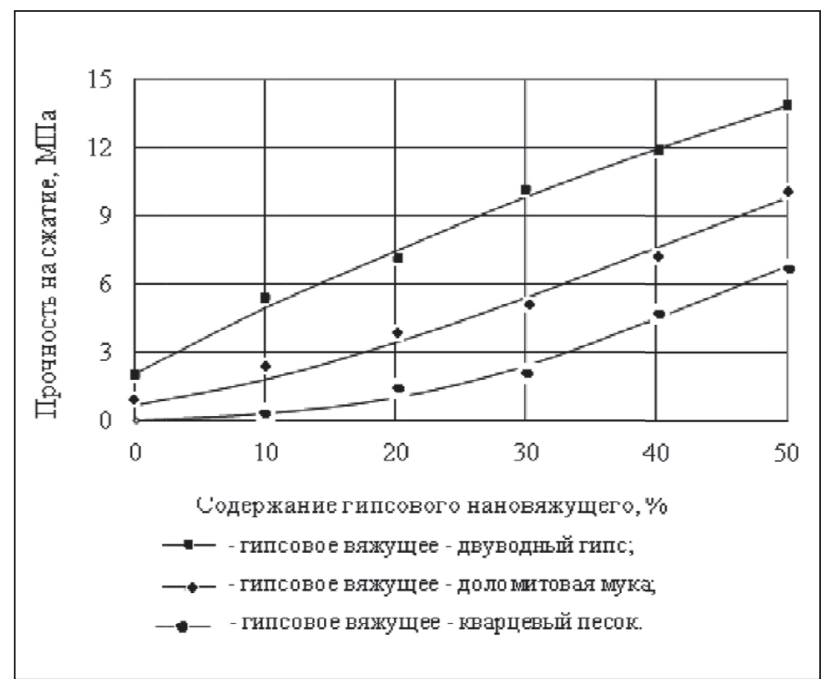

Рис. 1. Динамика роста прочности образцов различного состава в зависимости от содержания гипсового нановяжущего в возрасте 1 сут.

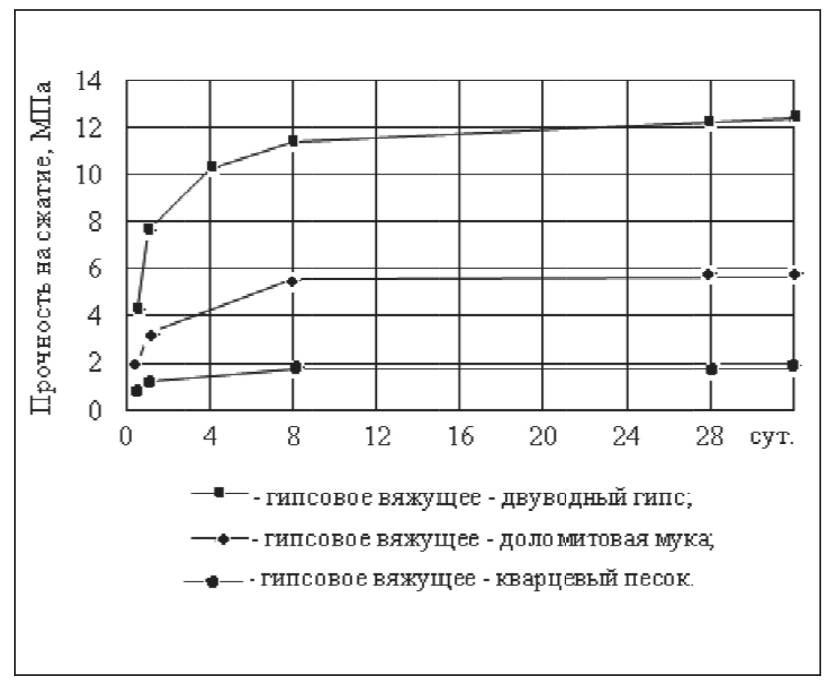

Рис. 2. Изменение прочности во времени прессованных образцов различного состава при содержании гипсового нановяжущего $20 \%$ 


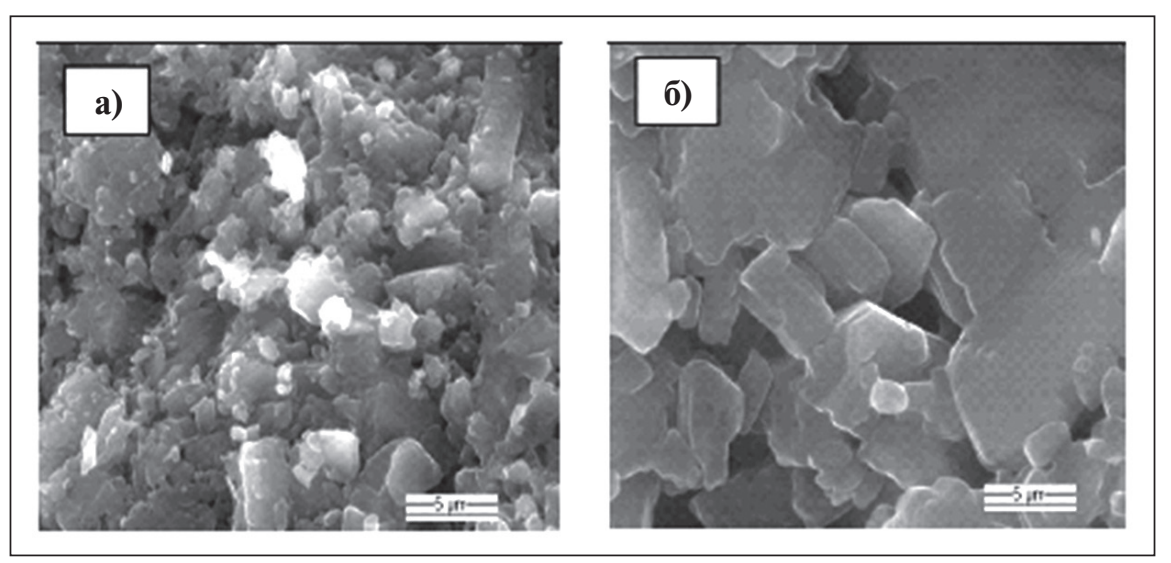

Рис. 3. Микроструктура прессованных нанокомпозитных гипсовых матриц. Время твердения: а) - 1 сут., б) - 8 сут.

вичной наноструктуры. При наличии в системе ДГ даже при небольшом содержании ПГ (не более 10\%) образуется трехмерная нанокристаллизационная структура с достаточно высокой прочностью.

Для изучения безгидратационного набора прочности затвердевшие образцы на основе гипсовых нановяжущих хранились в течение месяца при $\mathrm{t}^{\circ}=$ $20 \pm 2{ }^{\circ} \mathrm{C}$ и относительной влажности атмосферы $\varphi=$ $60 \pm 10 \%$. Кинетика изменения прочности на сжатие нанокомпозитных образцов приведена на рис. 2: заметный рост прочности на сжатие происходит в первые 4 сутки.

Микроструктура гипсовых нанокомпозитов исследована на растровом электронном микроскопе JEOL JSM-6610L. Электронномикроскопические снимки показывают (рис. 3) увеличение размеров микрокристаллов в течение 8 суток.

На базе данных лабораторных опытов была разработана технология получения мелкоштучных стеновых и перегородочных изделий, которая была апробирована в опытно-промышленных условиях. За счет использования технологий полусухого прессования и вибропрессования получены стеновые перегородочные стройматериалы с достаточной прочностью. Использование наночастиц техногенных отходов [12-14] позволяет ускорить кинетику набора прочности, повысить марку по водонепроницаемости и улучшить эксплуатационные характеристики композиционных гипсовых вяжущих. В работе [15] подробно рассмотрена технология получения мелкоштучных стеновых изделий полусухим прессованием на основе техногенного дигидрата фосфогипса.

Рассмотрение структурообразования и твердения фосфогипсовых стройматериалов с позиции фрактальной концепции корректно моделируется в виде мультифрактальных нанокластеров дигидрата суль- фата кальция размерами несколько десятков нанометров [16]. Фосфогипсовая нанокомпозиция с отходами производства соды твердеет за счет комплексных реакций с образованием гидросульфоалюминатов и гидросиликатов кальция. В статье [17] предложен метод количественного анализа изображений микроструктуры наномодифицированного композита, основанный на выполнении двоичной декомпозиции. Средние значения фрактальной размерности для эмпирических изображений микроструктуры составляют 1,63 (оптическая микроскопия) и 1,76 (сканирующая зондовая микроскопия).

При механоактивации высокопрочных гипсов [18] целесообразно ввести в сухую строительную смесь «FREM NANOGIPS»: это дает снижение водогипсового отношения и повышение в 3-6 раз прочностных характеристик получаемых нанокомпозитных гипсовых изделий и материалов; позволяет регулировать время схватывания, усиливает водостойкость, а также поверхностную твердость и адгезию [19] к различным твердофазным материалам. Авторами статьи [20] установлено, что при модифицировании $0,18 \%$ многослойными углеродными нанотрубками наблюдается прирост прочности на сжатие гипса до $29 \%$.

Инновационные материалы на базе гипсовых нанокомпозитных вяжущих (сухие штукатурные и шпаклевочные смеси) созданы модификацией $0,25-1 \%$ поливинилацетатными редиспергируемыми полимерами [21]. Модифицированные гипсовые сухие смеси обладают уникальными характеристиками: возможностью регулирования сроков схватывания в широких диапазонах, достаточной прочностью, водостойкостью и др.

Следует отметить, что регуляция твердения гипсовых вяжущих считается перспективным при конструировании исходных компонентов 3D-технологий 
THE ELABORATION OF THE THEORY OF THE FORMATION STRENGTH AND IMPERMEABILITY OF NANOSTRUCTURED SYSTEMS РАЗРАБОТКА ТЕОРИИ ФОРМИРОВАНИЯ ПРОЧНОСТИ И НЕПРОНИЦАЕМОСТИ НАНОСТРУКТУРИРОВАННЫХ СИСТЕМ

[22]. Аддитивные технологии представляют собой послойное добавление материала по компьютерной 3D-модели [23], и в настоящее время проектировщики в стройиндустрии все больше используют технологии 3D-печати, что обеспечивает быстроту возведения малоэтажных зданий со сложной конструкцией. Эффективным подходом усиления эксплуатационных характеристик строительных нанокомпозитов для 3D аддитивных технологий на базе гипсовых вяжущих является реализация регулируемого твердения с минеральными добавками.

\section{ВЫВОДЫ}

Таким образом, нарастание прочности в процессе твердения гипсовых нановяжущих определяется химико-минералогическим составом исходных сырьевых компонентов и идет параллельно изменению их микроструктуры. Технологические свойства гипсовых нанокомпозитов: сроки схватывания, водостойкость, прочность и др. можно регулировать, изменяя соотношение отдельных компонентов и введением техногенных наномодификатов.

\section{REFERENCES}

1. Chernishov E.M., Artamonova O.V., Slavcheva G.S. Nanotechnological applied tasks of the increase in the efficiency of the hardening processes of cement concrete. Nanotehnologii v stroitel'stve $=$ Nanotechnologies in Construction. 2017, Vol. 9, no. 1, pp. 25-41. DOI: dx.doi.org/10.15828/2075-8545-2017-9-1-25-41. (In Russian).

2. Belov V.V., Buryanov A.F., Yakovlev G.I. et al. Modification of the structure and properties of building composites based on calcium sulfate. Moscow: De Nova. 2012. 196 p. (In Russian).

3. Padevět P., Tesárek P., Plachý T. Evolution of mechanical properties of gypsum in time. International Journal of Mechanics. 2011. Vol. 5, no 1. P. 1-9.

4. Gypsum materials and products (production and use). Handbook / Ed. A.V. Ferronskaya. Moscow: Publ. ABU, 2004. 485 p. (In Russian).

5. Polak A.F., Babkov V.V., Andreeva E.P. Hardening mineral binders. Ufa: Bash. Publ. House, 1990. 215 p. (In Russian).

6. Klimenko V.G. Multiphase gypsum binders. Belgorod: BSTU named after V.G. Shukhov, 2010. 198 p. (In Russian).

7. Petropavlovskaya V.B., Belov V.V., Novichenkova T.B. Low-energy-intensive gypsum building composites. Tver: TSTU, 2014. 136 p. (In Russian).

8. Yu Q.L., Brouwers H.J.H. Microstructure and mechanical properties of $\beta$-hemihydrate produced gypsum: An insight from its hydration process. Constr. Build. Mater. 2011. Vol. 25. P. 3149-3157.

9. Mirsaev R.N., Babkov V.V., Nedoseko I.V. et al. Structural Formation and Hardening of Compressed Calcium Sulphate Dihydrate Compositions. Construction Materials. 2009. No. 6. P. 6-9. (In Russian).

10. Gaitova A.R., Akhmadullina I.I., Pechenkina T.V. et al. Nanostructural aspects of hydration and hardening of gypsum and gypsum-slag compositions based on two-water gypsum. Construction Materials. 2014. No. 1-2. P. 46-51. (In Russian).

11. Tokarev Yu.V., Ginchitsky E.O., Yakovlev G.I. et al. Modification efficiency of gypsum binder with carbon nanotubes and additives of different dispersity. Construction Materials. 2015. No. 6. P. 84-87. (In Russian).

12. Oratovska A.A., Sinitsyn D A., Galeeva L.S. et al. The use waste of production of sodium to obtain lime-containing binders and building materials on their basis. Construction Materials. 2012. No. 2. P. 52-53. (In Russian).

13. Khezhev T.A., Pukharenko Yu.V., Khezhev Kh.A. et al. Fiber gypsum concrete composites with using volcanic tuff sawing waste. Journal of Engineering and Applied Sciences. 2018. Vol. 13, no. 8. P. 2935-2946.

14. Khalikov R. M., Ivanova O. V. Technological schemes of solution of ecological problems of regional production of materials. Nauka-Rastudent.ru. 2014. No. 3(03). P. 10. (In Russian).

15. Mirsaev R.N., Babkov V.V., Yunusova S.S. et al. Phosphogypsum waste of the chemical industry in the production of wall products. Moscow: Chemistry, 2004. 176 p. (In Russian).

16. Sinitsin D.A., Khalikov R.M., Bulatov B.G. et al. Technological approaches to directed structure formation of construction nanocomposites with increased corrosion resistance. Nanotehnologii v stroitel'stve $=$ Nanotechnologies in Construction. 2019 , Vol. 11, no. 2, pp. 153-164. - DOI: 10.15828/2075-8545-2019-11-2-153-164. (In Russian).

17. Smirnov V.A., Korolev E.V., Danilov A.M. et al. Fractal analysis of the nano-modified composite microstructure. Nanotechnologies in construction. 2011. V. 3, no. 5, pp. 77-86. (In Russian).

18. Kuzmina V.P. Mechanisms of nanoadditives influence on gypsum products. Nanotechnologies in construction. 2012. V. 4, no. 3, pp. 98-106. (In Russian).

19. Mashukov N.I., Khalikov R.M., Kharaev A.M. Stabilization and modification of molecular structures. Saarbrucken: Palmarium Academic Publishing, 2014. 210 p. (In Russian).

20. Chumak A.G., Derevyanko V.N., Petrunin S.Yu. et al. Structure and properties of a composite material based on gypsum binder and carbon nanotubes. Nanotechnologies in construction. 2013. V. 5, no. 2, pp. 27-37. (In Russian). 
21. Panferova A.Yu., Garkavi M.S. Modification of gypsum systems with small additions of polymers. Construction Materials. 2011. No. 6. P. 8-9. (In Russian).

22. Chernysheva N.V., Glagolev E.S., Lesovik V.S. et al. Effective composites employing fast-hardening gypsum cement binders for additive manufacturing. Advances in Engineering Research. 2017. V. 133. P. 135-141.

23. Sergeeva O.Yu. Additive technologies and 3D modeling. Nanotehnologii v stroitel'stve $=$ Nanotechnologies in construction. 2018. V. 10, no. 4, pp. 142-158. DOI: dx.doi. org / 10.15828 / 2075-8545-2018-10-4-142-158. (In Russian).

\section{СПИСОК ЛИТЕРАТУРЫ}

1. Чернышов Е.М., Артамонова О.В., Славчева Г.С. Прикладные нанотехнологические задачи повышения эффективности процессов твердения цементных бетонов // Нанотехнологии в строительстве. - 2017. - Том 9, № 1. - С. 25-41. DOI: dx.doi.org/10.15828/2075-8545-2017-9-1-25-41.

2. Белов В.В., Бурьянов А.Ф., Яковлев Г.И. и др. Модификация структуры и свойств строительных композитов на основе сульфата кальция. - М.: Де Нова, 2012. - 196 с.

3. Padevět P., Tesárek P., Plachý T. Evolution of mechanical properties of gypsum in time // International Journal of Mechanics. - 2011. - Vol. 5, no. 1. - P. 1-9.

4. Гипсовые материалы и изделия (производство и применение). Справочник. / Под ред. А.В. Ферронской. - М.: Изд-во АСВ, 2004. - 485 с.

5. Полак А.Ф., Бабков В.В., Андреева Е.П. Твердение минеральных вяжущих веществ. - Уфа: Башк. кн. изд-во, 1990. -215 c.

6. Клименко В.Г. Многофазовые гипсовые вяжущие. - Белгород: БГТУ им. В.Г.Шухова, 2010. - 198 с.

7. Петропавловская В.Б., Белов В.В., Новиченкова Т.Б. Малоэнергоемкие гипсовые строительные композиты. Тверь: ТГТУ, 2014. - 136 с.

8. Yu Q.L., Brouwers H.J.H. Microstructure and mechanical properties of $\beta$-hemihydrate produced gypsum: An insight from its hydration process // Constr. Build. Mater. - 2011. - Vol. 25. - P. 3149-3157.

9. Мирсаев Р.Н., Бабков В.В., Недосеко И.В. и др. Структурообразование и твердение прессованных композиций на основе дигидрата сульфата кальция // Строительные материалы. - 2009. - № 6. - С. 6-9.

10. Гаитова А.Р., Ахмадуллина И.И., Печенкина Т.В. и др. Наноструктурные аспекты гидратации и твердения гипсовых и гипсошлаковых композиций на основе двуводного гипса // Строительные материалы. - 2014. - № 1-2. - С. 46-51.

11. Токарев Ю.В., Гинчицкий Е.О., Яковлев Г.И. и др. Эффективность модификации гипсового вяжущего углеродными нанотрубками и добавками различной дисперсности // Строительные материалы. - 2015. - № 6. - С. 84-87.

12. Оратовская А.А., Синицин Д.А., Галеева Л.Ш. и др. Использование отходов производства кальцинированной соды для получения известьсодержащих вяжущих и строительных материалов на их основе // Строительные материалы. - 2012. - № 2. - С. 52-53.

13. Khezhev T.A., Pukharenko Yu.V., Khezhev Kh.A. et al. Fiber gypsum concrete composites with using volcanic tuff sawing waste // Journal of Engineering and Applied Sciences. 2018. - Vol. 13, no. 8. - P. 2935-2946.

14. Халиков Р.М., Иванова О.В. Технологические схемы решения экологических проблем регионального производства материалов // Nauka-Rastudent.ru - 2014. - № 3(03). - C. 10.

15. Мирсаев Р.Н., Бабков В.В., Юнусова С.С. и др. Фосфогипсовые отходы химической промышленности в производстве стеновых изделий. - М.: Химия, 2004. - 176 с.

16. Синицин Д.А., Халиков Р.М., Булатов Б.Г. и др. Технологичные подходы направленного структурообразования нанокомпозитов строительного назначения с повышенной коррозионной устойчивостью // Нанотехнологии в строительстве. - 2019. - Том 11, № 2. - C. 153-164. - DOI: 10.15828/2075-8545-2019-11-2-153-164.

17. Смирнов В.А., Королев Е.В., Данилов А.М. и др. Фрактальный анализ микроструктуры наномодифицированного композита // Нанотехнологии в строительстве. - 2011. - Том 3, № 5. - C. 77-86. URL: http://nanobuild.ru/ru_RU (дата обращения: 18 января 2019 г.)

18. Кузьмина В.П. Механизмы воздействия нанодобавок на гипсовые продукты // Нанотехнологии в строительстве. 2012. - Том 4, № 3. - C. 98-106. - URL: http://nanobuild.ru/ru_RU (дата обращения: 19 января 2019 г.).

19. Машуков Н.И., Халиков Р.М., Хараев А.М. Стабилизация и модификация молекулярных структур. - Saarbrucken: Palmarium Academic Publishing, 2014. - $210 \mathrm{c}$.

20. Чумак А.Г., Деревянко В.Н., Петрунин С.Ю. и др. Структура и свойства композиционного материала на основе гипсового вяжущего и углеродных нанотрубок // Нанотехнологии в строительстве. - 2013. - Том 5, № 2. - С. $27-37$. URL: http://nanobuild.ru/ru_RU (дата обращения: 20 января 2019 г.)

21. Панферова А.Ю., Гаркави М.С. Модифицирование гипсовых систем малыми добавками полимеров // Строительные материалы. - 2011. - № 6. - С. 8-9.

22. Chernysheva N.V., Glagolev E.S., Lesovik V.S. et al. Effective composites employing fast-hardening gypsum cement binders for additive manufacturing // Advances in Engineering Research. - 2017. - V. 133. - P. 135-141.

23. Сергеева О.Ю. Аддитивные технологии и 3D-моделирование // Нанотехнологии в строительстве. - 2018. - Том 10, № 4. - C. 142-158. - DOI: dx.doi. org/10.15828/2075-8545-2018-10-4-142-158. 


\section{INFORMATION ABOUT THE AUTHORS}

Rauf M. Khalikov, Ph.D. in Chemistry, Ufa State Petroleum Technological University; Mendeleev st., 195, Ufa, Bashkortostan Republic, Russia, 450080; rauf_khalikov@mail.ru;

Ekaterina A. Sinitsina, assistant, Ufa State Petroleum Technological University; Mendeleev st., 195, Ufa, Bashkortostan Republic, Russia, 450080; sinitsina.katy@yandex.ru

Elena I. Silantyeva, master's student, Ufa State Petroleum Technological University; Mendeleev st., 195, Ufa, Bashkortostan Republic, Russia, 450080; silanteva.elena.ufa@gmail.com

Alexander N. Pudovkin, Ph.D. in Engineering, Kumertau branch of Orenburg State University; $2^{\text {nd }}$ Lane Soviet, 3B, Kumertau, Bashkortostan Republic, Russia, 453300; 11 pk@rambler.ru

Igor V. Nedoseko, Doctor of Engineering, Ufa State Petroleum Technological University; Mendeleev st., 195, Ufa, Bashkortostan Republic, Russia, 450080, nedoseko1964@mail.ru

\section{ИНФОРМАЦИЯ ОБ АВТОРАХ}

Халиков Рауф Музагитович, к.Х.н., доц. каф. «Строительные конструкции», ФГБОУ ВО «Уфимский государственный нефтяной технический университет»; ул. Менделеева, 195, г. Уфа, Республика Башкортостан, Россия, 450080, rauf_khalikov@mail.ru;

Синицина Екатерина Александровна, ассистент каф. «Строительные конструкции», ФГБОУ ВО «Уфимский государственный нефтяной технический университет»; ул. Менделеева, 195, г. Уфа, Республика Башкортостан, Россия, 450080, sinitsina.katy@yandex.ru;

Силантьева Елена Игоревна, магистрант каф. «Строительные конструкции», ФГБОУ ВО «Уфимский государственный нефтяной технический университет»; ул. Менделеева, 195, г. Уфа, Республика Башкортостан, Россия, 450080, silanteva.elena.ufa@gmail.com;

Пудовкин Александр Николаевич, к.т.н., доц. каф. «Производство строительных материалов», ФГБОУ ВО «Оренбургский государственный университет, Кумертауский филиал»; переулок 2-й Советский, д. 3Б, г. Кумертау, Республика Башкортостан, 453300; 11 pk@rambler.ru;

Недосеко Игорь Вадимович, д.т.н., проф. каф. «Строительные конструкции», ФГБОУ ВО «Уфимский государственный нефтяной технический университет»; ул. Менделеева, 195, г. Уфа, Республика Башкортостан, Россия, 450080, nedoseko1964@mail.ru 